\title{
Model Inquiry dalam Meningkatkan Hasil Belajar IPA Siswa Sekolah Dasar
}

\author{
Ventri Adetia Jumintri', Suhirman', Wiji Aziz Hari Mukti** \\ 'Institut Agama Islam Negeri Bengkulu, Bengkulu, Indonesia \\ "Corresponding author: wiji@iainbengkulu.ac.id
}

\begin{abstract}
Abstrak: Penelitian ini bertujuan untuk mengetahui penerapan Model Inkuiri untuk meningkatkan pemahaman IPA siswa kelas IV SDN 56 Kaur. Penelitian ini menggunakan metode Penelitian Tindakan Kelas (PTK). Responden penelitian ini adalah siswa kelas IV SDN 56 Kaur yang berjumlah 20 siswa. Hasil penelitian menunjukkan bahwa Model lquiry dapat meningkatkan penguasaan IPA siswa kelas IV SDN 56 Kaur. Peningkatan tersebut terlihat dari nilai rata-rata siswa pada pra-penilaian (53) yang termasuk dalam kategori "Rendah"; nilai rata-rata siswa pada siklus I $(57,38)$ yang termasuk dalam kategori "Rendah"; nilai rata-rata siswa pada siklus II $(62,13)$ yang termasuk dalam kategori "Sedang"; dan nilai rata-rata siswa pada siklus III $(65,88)$ yang termasuk dalam kategori "Sedang”. Artinya selama proses tindakan selama tiga siklus, siswa mengalami peningkatan sebesar $(12,88)$ poin. Kemajuan terpenting adalah peningkatan suasana belajar yang meliputi: perilaku siswa, motivasi belajar, dan interaksi siswa di dalam kelas. Selama tindakan berlangsung suasana belajar menjadi lebih aktif, siswa menghindari kegiatan yang tidak disiplin seperti mengobrol dengan teman, siswa terlihat memiliki motivasi yang tinggi dan senang mengikuti pelajaran IPA, dan dalam kegiatan kelompok mereka dapat berpartisipasi aktif dan memberikan kontribusi dalam memecahkan masalah. masalah dalam kelompoknya.
\end{abstract}

Kata Kunci: inquiry, hasil belajar, siswa, sekolah dasar

\begin{abstract}
This research aimed at investigating the implementation oflnquiry Model to improve students' understanding in science at the fourth grade stdents of SDN 56 Kaur. This research applied Classroom Action Research (CAR) method. The respondents of this research were the fourth grade stdents of SDN 56 Kaur that consisted of 20 students. The result of the research showed that lquiry Model could improve students' mastery of science at the fourth grade stdents of SDN 56 Kaur. The improvement can be seen from the students' avarage score in pre-assessment (53) that included into "Low" category; students' avarage score in cycle I (57.38) that included into "Low" category; students' avarage score in cycle II (62.13) that included into "Moderate" category; and students' average score in cycle III (65.88) that included into "Moderate" category. It means that during the process of action for three cycles, the students got improvement for (12.88) point. The most important progress was the improvement in learning atmosphere that covers: students' behaviour, learning motivation, and students' interraction in the classroom. During the action, the learning atmosphere became more active, the students avoid indicipline activities such as chatting with friends, the students looked have high motivation and happy to follow the science class, and in group activities, they can actively participate and gave contribution in solving problems in their group.
\end{abstract}

Keywords: inquiry, learning outcomes, students, elementary school

\section{PENDAHULUAN}

Dalam perkembangannya istilah pendidikan berarti bimbingan atau pertolongan yang diberikan dengan sengaja terhadap peserta didik oleh orang dewasa agar ia menjadi dewasa. Dalam perkembangan selanjutnya, pendidikan berarti usaha yang dijalankan oleh seseorang atau kelompok untuk mempengaruhi seseorang atau kelompok orang agar menjadi dewasa atau 
mencapai tingkat hidup dan penghidupan yang lebih tinggi dalam arti mental. Pendidikan dimulai dalam lingkungan keluarga atas anak (infant) yang belum mandiri, kemudian di perluas di lingkungan tetangga atau komunitas sekitar (milieu), lembaga persekolahan, persekolahan formal dan lain-lain tempat anak-anak mulai dari kelompok kecil sampai rombongan relatif besar (lingkungan makro) dengan pendidikan dimulai dari guru rombongan/kelas yang mendidik secara mikro dan menjadi pengganti orang tua.

Dalam UU Sisdiknas No 20 Tahun 2003 disebutkan bahwa: Pendidikan nasional adalah usaha sadar dan terencana untuk mewujudkan suasana belajar dan proses pembelajaran agar peserta didik secara aktif mengembangkan potensi dirinya untuk memiliki kekuatan spiritual keagamaan, pengendalian diri, kepribadian, kecerdasan, akhlak mulia serta keterampilan yang diperlukan dirinya, masyarakat bangsa dan negara. Selain itu, dalam Undang -Undang tersebut pada pasal 3 juga menyebutkan bahwasanya: Pendidikan nasional berfungsi mengembangkan kemampuan dan membentuk watak, serta peradaban bangsa yang bermartabat dalam rangka mencerdaskan kehidupan bangsa, bertujuan untuk berkembangnya potensi peserta didik agar menjadi manusia yang beriman dan bertakwa kepada Tuhan Yang Maha Esa, berakhlak mulia, sehat, berilmu, cakap, mandiri, kreatif dan menjadi warga Negara yang demokratis seta bertanggung jawab. Dalam rangka mewujudkan fungsi pendidikan tersebut, dalam pendidikan sekolah kegiatan pembelajaran merupakan kegiatan yang paling penting. Berhasil atau tidaknya tujuan pendidikan tersebut tergantung pada proses belajar yang dilakukan siswa.

Upaya untuk meningkatkan kemampuan siswa dalam berpikir kritis pada proses pembelajaran merupakan tantangan bagi setiap orang yang berkecimpung di dalam dunia pendidikan. Banyak usaha yang dilakukan, banyak juga keberhasilan yang telah dicapai, meski apa yang telah dicapai belum sepenuhnya memberikan kepuasan sehingga menuntut pemikiran dan kerja keras yang lebih. Upaya yang dilakukan dalam meningkatkan kemampuan berpikir kritis siswa dapat dilakukan melalui beberapa perbaikan pada proses pembelajaran. Dalam hal ini, guru memegang peran yang sangat penting, yaitu dengan menerapkan model pembelajaran yang tepat.

Salah satu model pembelajaran yang dapat meningkatkan kemampuan berpikir kritis siswa adalah model inkuiri. Model inkuiri adalah salah satu cara belajar atau penelaahan yang bersifat mencari pemecahan masalah dengan cara kritis, analitis, dan ilmiah dengan menggunakan langkah-langkah yang menuju suatu kesimpulan yang meyakinkan karena didukung oleh data atau kenyataan. Sasaran utama model inkuiri adalah mengembangkan penguasaan pengetahuan yang merupakan hasil dari pengolahan data atau informasi.

Berdasarkan hasil observasi awal dan wawancara peneliti dengan guru IPA pada tanggal 2 dan 4 Desember 2018 di kelas IV Pelaksanaan pembelajaran IPA SD Negeri 56 Kaur diketahui bahwa siswa masih kurang dalam melakukan pengamatan dan percobaan, disebabkan oleh kurangnya fasilitas belajar mengajar di dalam kelas terutama buku paket, serta media pembelajaran yang kurang memadai. Selain itu, pembelajaran IPA yang berlangsung selama ini lebih berpusat pada guru dengan menggunakan metode ceramah yang membuat siswa kurang aktif. Aktivitas guru masih sangat besar dibandingkan dengan aktivitas siswa, hal ini dapat dilihat dari kebiasaan guru yang hanya menulis pelajaran di papan lalu menerangkan sedangkan siswa lalai dengan aktivitasnya masing-masing tanpa memperhatikan apa yang diajarkan. Oleh karena itu siswa merasa jenuh dalam belajar IPA dan kurang memahami konsep yang diajarkan sehingga hasil pembelajaran tidak maksimal.

Dalam proses pembelajaran model yang digunakan guru juga belum bervariasi. Ini mengakibatkan hasil belajar siswa pada mata pelajaran IPA sangat kurang memuaskan, nilai ratarata siswa pada mata pelajaran IPA kelas IV SD Negeri 56 Kaur masih jauh dibawah standar KKM yang ditetapkan. KKM yang di tetapkan untuk mata pelajaran IPA kelas IV SD Negeri 56 Kaur adalah 65. Hal ini disebabkan oleh kurangnya pemahaman siswa terhadap materi pokok pembelajaran, siswa cenderung pasif dalam mengikuti setiap proses pembelajaran yang dilakukan di dalam kelas, walaupun ada beberapa siswa yang bersikap aktif dalam menjawab pertanyaan guru dengan pemahaman yang kurang memadai. Maka dari itu, penulis menyimpulkan bahwa 
dalam proses pembelajaran perlunya adanya model pembelajaran baru yang menarik perhatian siswa, salah satunya adalah menggunakan model pembelajran inquiri. Berdasarkan uraian tersebut, peneliti tertarik untuk melakukan penelitian mengenai penerapan model inquiry dalam meningkatkan hasil belajar IPA siswa kelas IV (empat) di SD Negeri 56 Kaur.

\section{METODE PENELITIAN}

Penelitian ini merupakan Penelitian Tindakan Kelas (Class Action Research). PTK merupakan metode yang cocok untuk penelitian pendidikan dan direkomendasikan dilakukan oleh guru atau pendidik karena akan memberikan manfaat baik bagi peneliti dan siswa yang menjadi objek penelitian. Penelitian ini dilaksanakan di SD Negeri 56 Kaur pada tanggal 26 April sampai dengan 7 Juni 2019. Penelitian ini dilaksanakan pada kelas IV SD Negeri 56 Kaur tahun akademik 2018/2019.

Dalam penelitian ini, peneliti mengambil kelas IV C sebagai responden penelitian yang terdiri dari 20 siswa. Kelas ini memenuhi syarat sebagai responden karena berdasarkan informasi dari guru bahwa kelas IV C masih memiliki masalah dalam pemahaman materi IPA.Kemudian, siswanya memiliki karakteristik heterogen-siswa memiliki kemampuan yang berbeda-beda.

Adapun Teknik Pengumpulan Data dalam penelitian ini yaitu: a) Teknik Pengumpulan Data Kualitatif Data kualitatif, dalam penelitian ini dikumpulan melalui beberapa instrumen, yaitu: lembar observasi siswa, lembar observasi guru, catatan lapangan dan wawancara. b) Teknik Pengumpulan Data Kuantitatif, untuk mengumpulkan data kuantitatif, peneliti menggunakan tes pada siswa. Yaitu seperangkat tes yang terdiri dari 40 soal IPA yang membahas berbagai topik Ilmu Pengetahuan Alam. Dalam penelitian ini, tes di lakukan beberapa kali, yaitu: tes/penilaian awal, tes/penilaian siklus I, tes/penilaian Siklus II, dan tes/penilaian seterusnya hingga siswa mencapai target penelitian.

Dalam mengumpulkan data, peneliti menggunakan beberapa instrument, yaitu: tes, lembar observasi, wawancara, dan dokumentasi. a) Tes, Peneliti menyiapkan tes yang berupa seperangkat soal IPA. Soal tersebut berbentuk pilihan ganda yang terdiri dari 40 soal. Soal-soal tersebut di ambil dari buku panduan guru yang belum pernah dibahas di kelas. Peneliti mendiskusikan soal-soal tersebut dengan kolaborator dan memilih soal yang pantas dan sesuai dengan tingkat kemampuan siswa kelas IV; b) Lembar Observasi, Peneliti merancang dua jenis lembar observasi, yaitu: lembar obserservasi siswa dan lembar observasi guru Lembar observasi siswa meliputi observasi mengenai kedisiplinan siswa selama proses tindakan, kemampuan dan partisipasi siswa dalam implementasi Model Inkuiri dalam pembelajaran IPA, dan aspek-aspek penting lainnya yang mendukung kesuksesan pembelajaran di kelas. Sedangkan lembar observasi guru meliputi kompetensi guru dalam menyampaian pelajaran terutama penguasaan dan implementasi Model Pembelajaran Inquiri selama proses pemberian tindakan. c) Wawancara, Dalam penelitian ini, peneliti menggunakan teknik wawancara tidak terstruktur dimana peneliti tidak menyiapkan pertanyaan terstruktur. d) Dokumentasi, yaitu proses mengumpulkan semua dokumen yang digunakan dalam penelitian. Peneliti akan mendokumentasikan semua hasil tes, hasil observasi, dan hasil wawancara pada bagian lampiran laporan penelitian. Selain sebagai pelengkap data penelitian, dokumentasi juga berguna sebagai pendukung keautentikan pelaksanaan penelitian. Teknik Analisis Data dalam penelitian ini yaitu: (1) Analisis Data Kualitatif, data kualitatif dalam penelitian ini diperoleh dari: lembar observasi siswa, lembar observasi guru, dan hasil wawancara. Untuk menganalisis data tersebut, peneliti menggunakan model interaktif dari Miles dan Huberman. Data analisis terdiri dari tiga komponen, yaitu: (a) pengumpulan data; (b) penyajian data; dan (c) menarik kesimpulan dan verifikasi kesimpulan.

Penelitian tindakan kelas (PTK) dikatakan berhasil apabila dilakukan tindakan kelas untuk memperbaiki kualitas pembelajaran, maka akan berdampak juga terhadap sikap siswa dan hasil belajar. Maka indikator kinerja pada penelitian ini adalah sebagai berikut: 1) Indikator keberhasilan pembelajaran minimal "bagus" (indikator ini untuk tujuan umum dari penelitian); 2) Secara kualitatif, indikator keberhasilan perbaikan perilaku siswa (misalnya: aspek sikap, motivasi belajar , keaktifan siswa, kerjasama, minat belajar, dan lain sebagainya); 3) Secara kuantitatif, 
indikator keberhasilan hasil belajar secara klasikal minimal $75 \%$ dari jumlah siswa yang mencapai KKM yang ditetapkan yaitu 65 secara perorangan.

\section{HASIL DAN PEMBAHASAN}

\section{A. Deskripsi Kondisi Awal sebelum Tindakan}

Sebelum memberikan tindakkan pada siswa, peneliti melakukan observasi kembali pada tanggal 26 April 2019 untuk memastikan bahwa belum terjadi perubahan pada kemampuan IPA siswa di kelas IV SDNegeri 56 Kaur. Pada tahap ini, peneliti melakukan observasi di kelas dengan memperhatikan tahap demi tahap pembelajaran IPA di kelas mulai dari pembukaan, kegiatan inti pembelajaran, hingga penutup.

Pada tahap awal pembelajaran kurangnya persiapan guru yang mengajar menyebabkan ketidak sempurnaan proses belajar mengajar. Guru tidak melakukan brain storminguntuk memberi semangat siswa dalam belajar. Selanjutnya, sguru juga tidak melakukan apersepsi untuk mengetahui sejauh mana pemahaman materi yang akan disampaikan guru. Pada tahap awal ini guru langsung menjelaskan pelajaran di depan kelas.

Pada tahap inti pembelajaran, guru masih menggunakan metode pembelajaran yang bersifat konvensional, dimana guru menjelaskan pelajaran dan siswa menjadi pendengar yang baik. Dengan kata lain, sistem pembelajaran masih bersifat teacher center. Selama proses belajar mengajar, guru dan siswa kurang berinteraksi secara intensif. Bahan ajar yang digunakan guru saat mengajar IPA tidak memadai sehingga tidak banyak sumber informasi yang dapat disampaikan pada siswa. Kemudian kurangnya media yang menyebabkan siswa kurang termotivasi untuk belajar, karena media yang menarik dapat meningkatkan semangat siswa dalam belajar.

Pada tahap akhir pembelajaran, guru hanya meminta siswa untuk bertanya tentang kesulitan yang dihadapi selama proses belajar. Namun, tak seorangpun siswa memberi respon. Guru tidak memberikan latihan untuk memperkuat pemahaman siswa mengenai materi yang disapaikan. Guru hanya memberikan pekerjaan rumah (PR) yang membuat siswa kebingungan dalam mengerjakannya. Tidak sampai di situ, dengan banyaknya masalah tersebut membuat siswa kurang aktif dalam proses belajar mengajar. Misalnya banyak siswa yang hanya diam saat di tanya. Saat mereka bertanya pun siswa tidak menggunakan bahasa Indonesia yang benar. Sedangkan siswa yanglainn hannya duduk dan menjadi pendengar.Sehingga dengan banyaknya siswa yang tidak aktif dalam proses pembelajaran berpengaruh terhadap hasil belajar siswa.

\section{B. Hasil Tes/Penilaian Awal}

Pada tahap awal penelitian, peneliti melakukan tes/penilaian awal pada siswa untuk mengetahui kemampuan dasar mereka mengenai pengetahuan IPA sebelum diberi tindakkan. Peneliti meminta siswa untuk melakukan tes dengan menggunakan instrumen tes yang telah disiapkan, berupa pertanyaan yang berjumlah 40 soal berbentuk pilihan ganda. Tes dinilai dengan menggunakan metode yang telah dijelaskan pada bab III. Tes/penilaian awal dini dilakukan pada tanggal 27 April 2019. Pada tahap penilaian awal ini, terdapat 20 siswa yang mengikuti tes.

Hasil tes awal menunjukkan bahwa, terdapat 5 siswa (25\%) siswa masuk ke dalam kategori 'cukup'; 11 siswa (55\%) masuk ke dalam kategori 'kurang'; 4 siswa (20\%) masuk ke dalam kategori 'sangat kurang'. Tidak ada siswa yang mendapatkan nilai 'Istimewa', 'Sangat Bagus', dan 'Bagus'. Pada tahap ini siswa memperoleh nilai rata-rata sebesar (53) dan masuk ke dalam kategori 'Kurang'. Dengan kata lain, hasil pembelajaran IPA siswa belum memenuhi standar kelulusan (KKM) dimana standar kelulusan siswa (KKM) untuk mata pelajaran IPA sebesar (65).

\section{Deskripsi Siklus I}

Siklus I dilaksanakan sebagai respon terhadap hasil penilaian/tes awal. Siklus I dilaksanakan selama empat kali pertemuan. Tiga kali pertemuan untuk memberikan tindakkan dengan menggunakan model Inkuiri; dan satu kali pertemuan untuk melakukan tes Siklus I untuk mengetahui peningkatan hasil belajar IPA siswa secara kuantitatif. Dalam pembelajaran ini, siswa 
dibagi menjadi kelompok kecil yang terdiri dari 5 siswa. Satu siswa menjadi ketua kelompok untuk menggerakkan anggota kelompoknya menjadi aktif selama pelajaran di kelas. Langkah yang di lakukan pada siklus 1 menggunakan beberapa tahapan, yaitu: tahap perencanaan, tahap pelaksanaan, tahap observasi, dan tahap refleksi.

1. Tahap Perencanaan

Sebelum memberikan tindakan, peneliti membuat rancangan pengajaran IPA dengan menggunakan model pembelajaran Inkuiri. Dalam perencanaan kegiatan, peneliti melaksanakan aktivitas sebagai berikut:

a) Menyusun rencana pelaksanaan pembelajaran (RPP). Peneliti mendiskusikan RPP yang telah disiapkan dengan kolaborator (Guru Kelas) agar mengetahui apakah level materi sudah sesuai dengan tingkatan siswa.

b) Menyiapkan seperangkat perangkat mengajar seperti: RPP, materi pengajaran, lembar kerja siswa, lembar observasi aktivitas siswa, lembar observasi kegiatan guru, dan alat-alat pendukung lainnya (gambar-gambar, buku, dan lembar kerja yang dapat menynjang proses pembelajaran). Perangkat mengajar tersebut dapat dilihat pada lampiran 5 (RPP Siklus 1 Pertemuan 1), Lampiran 18 (Lembar Observasi Siswa Siklus I Pertemuan 1), Lempiran 27 (Lembar Observasi Guru Siklus 1 Pertemuan 1).

c) Mengelompokkan siswa menjadi 4 kelompok. Setiap kelompok terdiri dari 5 siswa. Peneliti dibantu oleh kolaborator (guru kelas) untuk menentukan anggota kelompok agar setiap kelompok terdiri dari siswa yang memiliki kemampuan yang berbeda (heterogen).

d) Menentukan ketua kelompok agar mereka memiliki peran yang saling melengkapi dalam kelompok masing-masing.

e) Peneliti memperkenalkan Model Pembelajaran Inkuiri kepada semua siswa dalam belajar IPA.

Pada siklus 1 peneliti ingin mengetahui apakah hasil belajar siswa dapat meningkat setelah menerapkan model pembelajaran Inquiri.

2. Tahap Pelaksanaan

Siklus I dilaksanakan dalam empat kali pertemuan. Tiga kali pertemuan untuk memberikan tindakkan dengan menggunakan model Inkuiri; dan satu kali pertemuan untuk melakukan tes Siklus I untuk mengetahui peningkatan hasil belajar IPA siswa secara kuantitatif. Dalam melaksanakan siklus I, peneliti mengikuti instruksi yang telah dirancang dalam RPP.

\section{Tahap Pengamatan}

Observasi dilaksanakan oleh peneliti dan kolaborator (Guru Kelas) selama proses belajar mengajar berlangsung. Pada tahap pengamatan, semua data dan informasi telah dikumpulkan melalui beberapa sumber, yaitu: lembar observasi siswa, lembar observasi guru, dan hasil tes siklus I. Dalam melakukan observasi atas pelaksanaan pembelajaran IPA dengan menggunakan model Inkuiri, peneliti memiliki beberapa catatan berdasarkan data yang telah dikumpulkan melalui instrumen lembar observasi siswa, lembar observasi guru, hasil tes siklus I, dan wawancara.

\section{Tahap Refleksi}

Dalam pengimplementasian metode Inkuiri dalam pembelajaran IPA pada Siklus I, ada beberapa perkembangan atau peningkatan yang dicapai oleh siswa. Namun juga ada beberapa hal yang harus dirancang dan di organisasikan kembali agar memberikan perubahan pada siklus selanjutnya. Peningkatan dan perkembangan yang dicapai siswa selama siklus I adalah: Nilai ratarata siswa pada siklus I meningkat yaitu $(57,38)$ yang masuk ke dalam kategori "Kurang". Angka ini meningkat dan lebih baik jika dibandingkan dengan hasil tes/penilaian awal yaitu (53) yang masuk dalam kategori "Kurang" walaupun hasil ini belum memuaskan dan belum mencapai target penelitian. Namun, ada beberapa hal penting yang harus dirancang dan diorganisasi ulang agar mencapai perbaikan maksimal pada siklus selanjutnya. 


\section{Deskripsi Siklus II}

Siklus II dilaksanakan sebagai respon terhadap hasil siklus I. Siklus II dilaksanakan selama empat kali pertemuan. Tiga kali pertemuan untuk memberikan tindakkan dengan menggunakan model Inkuiri; dan satu kali pertemuan untuk melakukan tes Siklus II untuk mengetahui peningkatan hasil belajar IPA siswa secara kuantitatif. Dalam pembelajaran ini, siswa dibagi menjadi kelompok kecil yang terdiri dari 5 siswa. Satu siswa menjadi ketua kelompok untuk menggerakkan anggota kelompoknya menjadi aktif selama pelajaran di kelas. Langkah yang di lakukan pada siklus II menggunakan beberapa tahapan, yaitu: tahap perencanaan, tahap pelaksanaan, tahap observasi, dan tahap refleksi.

Peningkatan dan perkembangan yang dicapai siswa selama siklus II adalah: Nilai rata-rata siswa pada siklus II meningkat yaitu $(62,13)$ yang masuk ke dalam kategori "cukup". Angka ini meningkat dan lebih baik jika dibandingkan dengan hasil tes Siklus I yaitu $(57,38)$ yang masuk dalam kategori "Kurang" walaupun hasil ini belum memuaskan dan belum mencapai target penelitian.

\section{E. Deskripsi Siklus III}

Siklus III dilaksanakan sebagai respon terhadap hasil siklus II . Siklus III dilaksanakan selama empat kali pertemuan. Tiga kali pertemuan untuk memberikan tindakkan dengan menggunakan model Inkuiri; dan satu kali pertemuan untuk melakukan tes Siklus II untuk mengetahui peningkatan hasil belajar IPA siswa secara kuantitatif. Dalam pembelajaran ini, siswa dibagi menjadi kelompok kecil yang terdiri dari 5 siswa. Satu siswa menjadi ketua kelompok untuk menggerakkan anggota kelompoknya menjadi aktif selama pelajaran di kelas. Langkah yang di lakukan pada siklus III menggunakan beberapa tahapan, yaitu: tahap perencanaan, tahap pelaksanaan, tahap observasi, dan tahap refleksi.

Dalam pengimplementasian model Inkuiri dalam pembelajaran IPA pada Siklus III, ada beberapa perkembangan atau peningkatan yang dicapai oleh siswa. Peningkatan dan perkembangan yang dicapai siswa selama siklus III adalah: Nilai rata-rata siswa pada siklus III meningkat yaitu $(65,88)$ yang masuk ke dalam kategori "Cukup". Angka ini meningkat dan lebih baik jika dibandingkan dengan hasil tes/penilaian siklus II yaitu $(62,13)$ yang masuk dalam kategori "cukup" walaupun hasil ini belum memuaskan dan namun sudah mencapai target mencapai target penelitian.

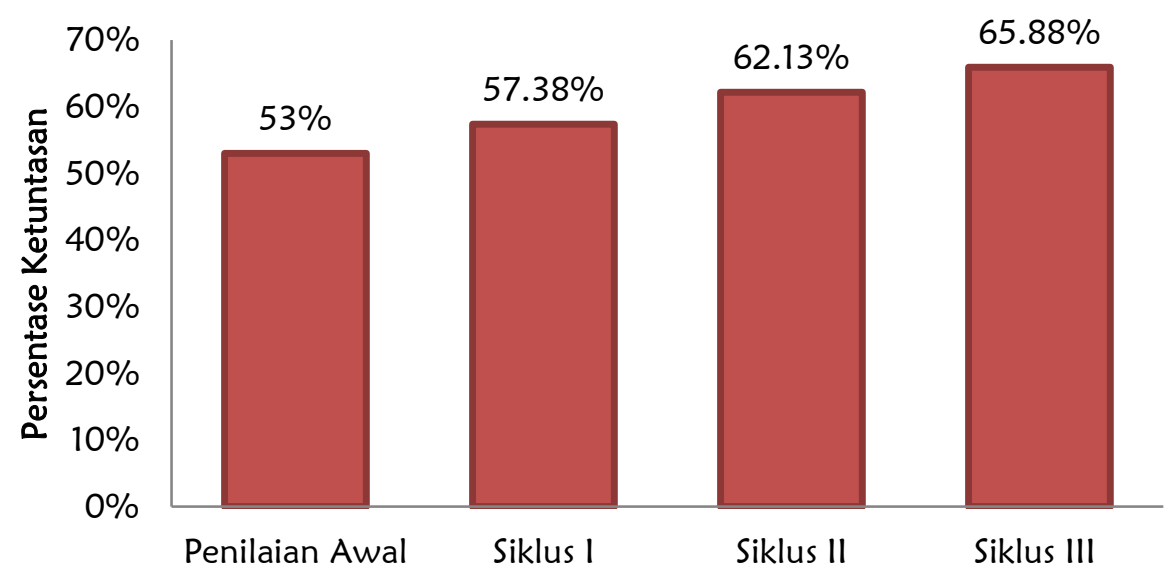

Gambar 1. Peningkatan Hasil Belajar Siswa dalam Pembelajaran IPA

Gambar 1 menunjukkan bahwa nilai rata-rata siswa dari tes awal hingga siklus III meningkat secara signifikan. Pada penilaian awal, siswa mendapat nilai rata-rata (53) yang masuk ke dalam kategori "Kurang". Kemudian, pada tes siklus I, siswa mendapatkan nilai rata-rata $(57,38)$ termasuk ke dalam kategori "Kurang". Pada tes siklus II siswa mendapat nilai rata-rata $(62,13)$ termasuk ke dalam kategori "Cukup". Pada tes siklus III, siswa meningkat secara signifikan. 
Siswa mendapatkan nilai rata-rata $(65,68)$ dan masuk ke dalam kategori "Cukup". Dalam fase ini, peneliti menghentikan pemberian tindakan karena siswa telah mencapai target penelitian.

\section{KESIMPULAN}

Setelah melaksanakan penelitian dan analisis data, kesimpulan penelitian ini adalah Model Inkuiri dapat meningkatkan hasil belajar IPA siswa kelas IV SD Negeri 56 Kaur. Peningkatan dapat dilihat dari nilai rata-rata siswa pada tes/penilaian awal yaitu (53) yang masuk ke dalam kategori "Kurang"; dan nilai rata-rata siswa pada tes/penilaian siklus III yaitu $(65,88)$. Berarti selama proses pemberian tindakan selama tiga siklus, siswa mengalami peningkatan sebanyak $(12,88)$ poin. Peningkatan yang lebih penting adalah perubahan yang terjadi pada suasana belajar siswa di kelas, terutama yang menyangkut: sikap, motivasi belajar, dan interaksi siswa di kelas. Selama proses tindakan, suasana belajar menjadi semakin aktif, siswa mengurangi tindakan-tindakan tidak disiplin di kelas, siswa juga lebih bersemangat dan bahagia mengikuti pelajaran, dan dalam kegiatan kelompok mereka dapat lebih berpartisipasi aktif dan berkontribusi dalam pemecahan masalah dalam kelompok mereka.

\section{DAFTAR PUSTAKA}

Ahmadi, K \& Setyono, H.A. (2011). Strategi Pembelajaran Berorientasi KTSP. Jakarta : PT. Prestasi Pustakaraya.

Arikunto, S., Suhardjono, \& Supardi.(2008). Penelitian Tindakan Kelas. Jakarta : PT Bumi Aksara.

Anam, K. (2016). Pembelajaran Berbasis Inquiri. Yogyakarta: Pustaka Pelajar.

Aunurrahman.(2014). Belajar Dan Pembelajaran. Bandung : Alfabeta.

Djamarah, S. Bahri. (2011). Psikologi Belajar. Jakarta : Rineka cipta.

Djumhana, N. (2012). Pembelajaran Ilmu Pengetahuan Alam. Jakarta: Direktorat.

Gulo, W. (2002). Strategi Belajar Mengajar. Jakarta: PT. Grasindo.

Gusa, A. (2009). UU SISDIKNAS dan UU GURU DAN DOSEN. Jakarta: Asa Mandiri.

Hamdani.(2011). Strategi Belajar Mengajar. Bandung: Pustaka Setia.

Hamalik, O. (2000). Proses Belajar Mengajar. Jakarta: Bumi Aksara.

Hartiny Sam's, R. (2010). Model Penelitian Tindakan Kelas. Yokyakarta:Teras.

Jenderal Departemen Agama RI. (2000).Al-Quran dan Terjemahannya. Bandung : Deponegoro.

Jihad, A \& Haris, A. (2013). Evaluasi Pembelajaran. Yogyakarta: Multi Pressindo.

Miles, M. B. \& Huberman, A. M. (1994). Qualitative Data Analysis: A Sourcebook Third Edition. USA: Sage Publishing.

Muhammad, A. (2000). Penelitian Tindakan Kelas. Bandung: CV Wacana Prima.

Ramayulis.(2015). Dasar-Dasar Kependidikansuatu Pengantar IImu Kependidikan. Jakarta: Kalam Mulia.

Rust, F \& Clerk, C. (2012). How to Do Action Research in Your Classroom.USA :Teachers Network Leadership Institute.

Sanjaya, W. (2006). Strategi Pembelajaran. Jakarta: Kencana Prenada Media Group.

Setiasih, S.L, dkk. (2016). Penggunaan model inquiri untuk meningkatkan hasil belajar siswa pada materi sifat-sifat magnet di kela $\mathrm{V}$ SDN sukajaya kecamatan jatinunggal kabupaten sumedang. Jurnal pena ilmiah.

Subur.(2015). Pembelajaran Nilai Moral Berbasis Kisah. Yogyakarta: Kalimedia.

Sukarjo \& Ukim, K. (2009). Landasan Pendidikan Konsep Dan Aplikasinya. Jakarta : PT. Rajagrafindo Persada.

Sulistyorini, S. (2007). Model Pembelajaran IPA Sekolah Dasar dan Penerapannya dalam KTSP. Yogyakarta: Tiara Wacana.

Tomal, D. R. (2003). Action Research for Educators. Oxford: The Scarecrow Press, Inc.

Trianto.(2007). Model-Model Pembelajaran Inovatif Berorientasi Konstruktivistik. Jakarta: PT. Prestasi Pustakaraya.

Trianto.(2009). Mengembangkan Model Pembelajaran Tematik. Jakarta : PT. Prestasi Pustakaraya. 
Trianto. (2013). Model Pembelajaran Terpadu Konsep, Strategi, Dan Imlpementasinya Dalam Kurikulum Tingkat Satuan Pendidikan (KTSP). Jakarta: Bumi Aksara.

Walid, A. (2017). Strategi Pembelajaran IPA. Yogyakarta:Pustaka Pelajar.Pendidikan Islam Kementrian Agama Republic Indonesia.

Wisudawati, A. W \& Sulistyowati, E. (2014). Metodologi Pembelajaran IPA. Jakarta: PT. Bumi Aksara. 